\title{
PERANAN MINUMAN DARI EKSTRAK JAHECANG UNTUK MENINGKATKAN KESEHATAN MASYARAKAT
}

\author{
Anik Supriani \\ Dosen Prodi Keperawatan, Sekolah Tinggi Ilmu Kesehatan Dian Husada Mojokerto \\ email: aniksupriani76@gmail.com
}

\begin{abstract}
Abstrak
Minuman ekstrak jahecang merupakan minuman penghangat yang bahannya berasal dari rempahrempah tanaman obat jahe, secang, kapulaga, daun sereh ditambah peerasanya kayu manis dan daun mint. Terdapatnya bahan-bahan berkhasiat tersebut dalam ekstrak jahecang telah terbukti bermanfaat bagi kesehatan, saat ini mulai banyak dicari orang untuk menyelesaikan permasalahan kesehatan terutama dalam pencegahan penyakit. Tujuan penulisan ini adalah untuk mengetahui peranan minuman dari ekstrak jahecang. Metodelogi penulisan ini dilakukan dengan pendekatan metode studi referensi. Data yang diambil ada dua jenis yaitu data primer dan data sekunder. Data primer diperoleh dari survey terhadap responden yang telah mengkonsumsi ekstrak jahecang yang ditentukan secara sengaja. Data sekunder diperoleh dari berbagai sumber diantaranya jurnal, prosiding seminar, laporan penelitian, dan tesis. Hasil studi menunjukkan bahwa beberapa bahan dalam minuman ekstrak jahecang dapat mencegah dan meminimalkan terjadinya penyakit degeneratif yaitu antioksidan, menurunkan kolesterol, mencegah osteoporososis anti diare, anti kanker, sehigga masyarakat yang minum ekstrak jahecang dapat meningkat kesehatannya. Diperlukan semangat, kemauan, kemampuan, pengetahuan dan ketrampilan untuk melestarikan, dan mengembangkan minuman ekstrak jahecang sehingga masyarakat bukan hanya tahu akan tetapi memahami manfaatnya yang banyak selain untuk apek-capek dan masuk angin.
\end{abstract}

Kata Kunci: ekstrak jahecang, kesehatan masyarakat

\section{PENDAHULUAN}

Penggunaan beberapa tumbuhan yang biasanya digunakan untuk bumbu masak sebagai obat tradisional sudah dilakukan sejak dahulu. Pengobatan tradisional ini sudah terbukti dapat membantu mengatasi masalah kesehatan selama beberapa generasi. Perkembangan obat tradisional atau yang dikenal masyarakat sebagai jamu seiring dengan kepercayaan masyarakat atas khasiat dan mutu jamu itu sendiri. Jika tidak adanya bukti bahwa jamu bisa untuk dijadikan sarana penyembuhan dan pemelihara kesehatan, tentu masyarakat enggan untuk mengkonsumsi jamu tersebut. Seiring dengan modernisasi dalam bidang kesehatan, sebagian orang mulai enggan menggunakan tanaman obat dalam menjaga kesehatan. Oleh karena enggannya dalam penggunaan obat tradisional, maka penerapan penggunaan tanaman obat akan berkurang, sehingga lama kelamaan pengetahuan mengenai tanaman obat dapat hilang.Hariana (2007). Oleh karena itu, perlu adanya suatu penelitian untuk membuktikan kebenaran khasiat dari ramuan tanaman obat (jahe, secang, kapulaga) dalam bentuk ekstrak dapat meningkatkan kesehatan masyarakat. Adanya kebenaran khasiat dari ramuan tanaman obat ini, dapat digunakan sebagai dasar pengelolaan sumber daya alam khususnya tumbuhan obat. 
Selain itu, perlu dilakukan sosialisasi kepada masyarakat dalam pemanfaatan tumbuhan obat untuk kesehatan diri, sehingga diharapkan nantinya memiliki keinginan, berinisiatif untuk melestarikan dan membudidayakan tumbuhan obat.

Penulis menetapkan Perum Japan Asri, Desa Japan Kecamatan Sooko, Kabupaten Mojokerto, sebagai tempat penelitian. Hal ini dikarenakan berdasarkan penelitian yang pernah dilakukan, di Kecamatan ini masih ada masyarakat yang menggunakan tumbuhan obat sebagai kesehatan.

\section{KAJIAN TEORI}

\section{Bahan-bahan ekstark jahecang}

\section{a. Kayu Secang}

Kayu secang mengandung zat berkhasiat sebagai anti oksidan kuat yang dapat meredam bahaya radikal bebas yang menjadi penyebab timbulnya penyakit kronis seperti kanker, jantung koroner, hipertensi, diabetes. (Triyono,Agus, 2011). Dalam pengobatan tradisional kayu secang biasa digunakan dengan cara diseduh untuk mengurangi penyakit antara lain :Batuk berdarah (TBC), diare, disentri, penawar racun, obat luka dalam dan luka luar, pengobatan sesudah persalinan, katarak, maag, rematik, masuk angin dan capek-capek. (Shahidi, 1999; Miller,2002).

Ekstrak kayu secang (Caesalpinia sappan L.) hasil penapisan mengandung lima senyawa aktif yang terkait dengan flavonoid baik sebagai antioksidan primer maupun antioksidan sekunder (Safitri, 2002). Pemberian ekstrak kayu secang ( Caesalpinia sappan L.) pada mencit yang terpapar aflatoksin diharapkan dapat menghamba $t$ menurunnya angka SAT sehingga kerusakan hati dapat dihindari. Telah diketahui bahwa flavonoid yang ter dapat dalam ekstrak kayu secang memiliki sejumlah kemampuan yaitu dapat meredam atau menghambat pembentukan radikal bebas hidroksil, anion superoksida, radikal peroksil, radikal alkoksil, singlet oksigen, hidrogen peroksida (Shahidi, 1999; Miller,2002).
Tanaman secang (Caeselpinia sappan, L) termasuk dalam familia Caesalpiniaceae. Tanaman ini mengandung resin, resorsin, brazilin, d-alfa phallandren, oscimenen, dan minyak atsiri. Secara empiris tanaman secang telah digunakan untuk mengatasi gout, rematik dan pembengkakan. Senyawa aktif yang terkandung dalam tanaman secang diduga bertanggung jawab dalam menghambat produksi asam urat di tubuh, sehingga produksi komplikasi hiperurecimea berupa gout arthritis tidak terjadi. Hasil penelitian Fitri Rahmawati (2011) menunjukkan bahwa tanaman secang memiliki aktivitas sebagai penurun asam urat darah tikus putih jantan galur SD. Dosis 40 $\mathrm{mg} / \mathrm{kg}$ bb menghasilkan penurunan kadar asam urat darah yang paling besar dibandingkan dengan dosis lain dan setara dengan alupurinol $50 \mathrm{mg} / \mathrm{kg}$ bb. Ekstrak etanol $70 \%$ kayu secang mengandung golongan senyawa kimia flavanoid, tannin polifenol, kardenolin dan antrakinon. Ekstrak kayu secang dosis 40 $\mathrm{mg} / \mathrm{kg}$ bb dapat digunakan sebagai salah satu alternatif dalam penanganan kasus hiperuricemia, karena mempunyai aktivitas yang setara dengan aktivitas alopurinol dosis 50 $\mathrm{mg} / \mathrm{kg}$ bb (Agus Triyono, 2011)

Kayu secang bermanfaat sebagai penangkal radikal bebas, antibiotic alami, membantu tubuh menyerap vitamin $\mathrm{C}$, menghentikan perdarahan, mengurangi rasa sakit dan nyeri, mengobati kanker prostat, memelihara kesehatan jantung, sebagai anti bakteri, mengobati sakit peru, sebagai anti inflamasi, terapi detoksifikasi, mengandung anti jamur, mengatasi obesitas, mengobati radang usus, menurunkan tekanan darah, mengobati penyakit TBC, menghngatkan tubuh, meningkatkan kekebalan tubuh (Agus Triyono, 2011)

\section{b. Jahe}

Jahe (Zingiber officinale), adalah tanaman rimpang yang sangat populer sebagai rempahrempah dan bahan obat. Rimpangnya berbentuk jemari yang menggembung di ruas-ruas tengah. 
Rasa dominan pedas disebabkan senyawa keton bernama zingeron.Jahe termasuk suku Zingiberaceae (temu-temuan). Nama ilmiah jahe diberikan oleh William Roxburgh dari kata Yunani zingiberi, dari bahasa Sansekerta, singaberi (Rukmana, 2000)

Jahe termasuk rempah yang banyak digunakan dan diperdagangkan dalam bentuk segar, kering maupun produk olahannya. Sebelum diolah lebih lanjut saat disimpan jahe segar memiliki beberapa kerugian seperti memerlukan banyak tempat, mutu dan aroma yang bervariasi tergantung pada umur, selama penyimpanan memungkinkan kehilangan minyak atsiri atau komponen lainnya. Pengembangan produk jahe kering dalam berbagai bentuk produk antara maupun produk jadi sangat menguntungkan, hal ini disebabkan karena permintaan pasar yang cukup tinggi baik di dalam maupun di luar negeri, dengan demikian memberikan peluang untuk dikembangkan secara serius oleh petani, industri makanan dan minuman maupun industri farmasi. Penggunaan jahe untuk berbagai macam olahan selain mempunyai rasa dan aroma yang enak dan khas, juga memiliki fungsi sebagai obat yaitu untuk memperbaiki pencernaan, menambah nafsu makan, memperkuat lambung dan mencegah infeksi. Hal ini disebabkan oleoresin pada jahe dapat merangsang selaput lendir perut besar dan usus. Selain itu juga untuk obat batuk, rematik, sakit kepala dan berguna untuk wanita yang baru melahirkan (Rodriquez, 1971). Dalam masyarakat Indonesia, pemanfaatan obat tradisional dalam sistem pengobatan sudah membudaya dan cenderung terus meningkat. Salah satu tanaman rempah dan obat-obatan yang ada di Indonesia adalah jahe (Rukmana, 2000).

\section{c. Kayu Manis dan Daun Kayu Manis}

Kayu manis dan Daun Kayu manis membuat rasa "Wedang Uwuh" menjadi lebih nikmat juga memiliki sifat antioksidan. Banyak herbalis meyakini bahwa campuran jahe dan kayu manis berkhasiat untuk meningkatkan daya tahan tubuh karena kandungan antioksidannya tinggi. Sundari (2001) menerangkan bahwa kayu manis adalah salah satu jenis rempah-rempah yang banyak digunakan sebagai bahan pemberi aroma dan citarasa dalam makanan dan minuman, dan bahan aditif pada pembuatan parfum serta obatobatan.

\section{d. Akar Sereh dan Daun Sereh}

Akar Sereh sejak lama digunakan sebagai peluruh air seni, peluruh keringat, peluruh dahak / obat batuk, bahan untuk kumur, dan penghangat badan. Daun: digunakan sebagai peluruh angin perut, penambah nafsu makan, pengobatan pasca persalinan, penurun panas dan pereda kejang. Tanaman sereh dipergunakan dalam berbagai kebudayaan. Bagian dari tanaman ini yang bisa dipakai untuk herbal meliputi akar, batang, dan daunnya. Manfaat sereh antara lain mencegah kanker, obat gangguan pencernaan, detoksifikasi, menurunkan tekanan darah, menghaluskan kulit, sebagai analgesic, menjaga kesehatan wanita. (Anggraini Lubis, 2011).

\section{e. Kapulogo}

Kapulaga atau di sebut juga Amomum cardamomum selama ini dikenal sebagai rempah untuk masakan dan juga lebih banyak digunakan untuk campuran jamu. Di Indonesia tanaman kapulaga dikembangkan sejak lama, terutama di daerah Jawa dan Sumatera. Biji kapulaga lokal dipercaya mengandung minyak atsiri, bahkan lebih harum, sehingga dulu sering dijadikan mut-mutan untuk pengharum mulut. Sayangnya, sejak dunia kebanjiran beragam permen penghilang bau mulut, kapulaga lokal tidak dipakai lagi karena dianggap kurang praktis ( Anonim, 2011)

Biji, yang diambil dari tumbuhan sebelum buah masak benar, dapat dimanfaatkan sebagai obat. Dalam dunia obat-obatan biji yang telah dikeringkan dinamakan semen cardamomi.(Anonim, 2011). Selain bijinya, yang digunakan untuk obat adalah bagian akar, 
buah, dan batangnya. Kapulaga mengandung minyak atsiri, sineol, terpineol, borneol, protein, gula, lemak, silikat, betakamfer, sebinena, mirkena, mirtenal, karvona, terpinil asetat, dan kersik. Dari kandungan tersebut kapulaga memiliki khasiat sebagai obat batuk. Kapulaga juga memiliki khasiat untuk mencegah keropos tulang (Anonim, 2011).

\section{f. Daun mint}

Tanaman dengan aroma yang beri kesegaran ini adalah tanaman yang telah mulai sejak lama dipakai dalam beragam budaya, salah satunya seperti di Timur Tengah, Eropa serta India. Ciri khas dari tanaman ini yaitu rasa manis dibarengi sensasi dingin beri kesegaran sesudah menyantapnya. Selain itu, suatu kenyataan teranyar menyampaikan bahwa daun mint yang tumbuh di Asia memiliki rasa yang tambah lebih kuat dari daun mint yang ada di Eropa, diluar itu rasa manis serta sensasi dinginnya juga lebih khas. Terkecuali jadikan juga sebagai bahan pelengkap rasa, daun mint juga mempunyai beberapa faedah besar untuk kesehatan. Faedah ini dapat anda peroleh dari mengonsumsinya dengan cara segera ataupun berupa ekstrak maupun minyak.

Maanfaat dan khasiat daun mint: Ampuh Tangani Masalah Pencernaan, Ampuh Kurangi Kemungkinan Alergi Ampuh Menyembuhkan Masalah Pernapasan Membuat kulit kepala jadi segar, ampuh menangani bau mulut, ampuh melakukan perbaikan kulit, mencegah kanker,

Kesehatan masyarakat menurut Winslow (1920), Kesehatan Masyarakat (Public Health) adalah ilmu dan seni mencegah penyakit, memperpanjang hidup dan meningkatkan kesehatan melalui "Usaha-usaha Pengorganisasian Masyarakat" untuk perbaikan sanitasi lingkungan, pemberantasan penyakitpenyakit menular, pendidikan untuk kebersihan perorangan, Pengorganisasian pelayananpelayanan medis dan perawatan untuk diagnosis dini dan pengobatan.

Menurut Hendrick L. Blumm, (Amalia,2009) terdapat 4 faktor yang mempengaruhi derajat kesehatan masyarakat, yaitu: faktor perilaku, faktor lingkungan, faktor keturunan, dan pelayanan kesehatan. Perilaku sehat akan menunjang meningkatnya derajat kesehatan, hal ini dapat dilihat dari banyaknya penyakit berbasis perilaku dan gaya hidup. Kebiasaan pola makan yang sehat dapat menghindarkan diri kita dari banyak penyakit, diantaranya penyakit jantung, darah tinggi, stroke, kegemukan, diabetes mellitus dan lain lain. Perilaku / kebiasaan mencuci tangan sebelum makan juga dapat menghindarkan kita dari penyakit saluran cerna seperti mencret mencret dan lainnya.

Saat ini pemerintah telah berusaha memenuhi 3 aspek yang sangat terkait dengan upaya pelayanan kesehatan, yaitu upaya memenuhi ketersediaan fasilitas pelayanan kesehatan dengan membangun Puskesmas, Pustu, Bidan Desa, Pos Obat Desa, dan jejaring lainnya (Amalia, 2009). Pelayanan rujukan juga ditingkatkan dengan munculnya rumah sakit rumah sakit baru di setiap kabupaten / kota.

\section{METODOLOGI PENELITIAN}

Penulis menetapkan Perum Japan Asri Desa Japan Kecamatan Sooko, Kabupaten Mojokerto, sebagai tempat penelitian. Hal ini dikarenakan berdasarkan penelitian yang pernah dilakukan, di Kecamatan ini masih ada masyarakat yang menggunakan tumbuhan obat sebagai kesehatan.

Kajian ini dilakukan dengan pendekatan metode studi referensi. Data yang diambil ada dua jenis yaitu data primer dan data sekunder. Data primer diperoleh dari survey terhadap responden yang telah mengkonsumsi ekstrak jahecang yang ditentukan secara sengaja. Data sekunder diperoleh dari berbagai sumber diantaranya jurnal, prosiding seminar, laporan penelitian, dan tesis. Selanjutnya data dianalisis secara diskriptif kwalitatif dalam bentuk tabel, gambar atau grafik. Selanjutnya dinarasikan untuk menjawab permasalahan kajian. 


\section{HASIL DAN PEMBAHASAN}

\section{Ekstrak jahecang dapat meningkatkan kesehatan}

\section{Bahan-bahan ekstrak jahecang}

Jahe

Jahe merupakan salah satu bumbu dapur yang banyak digunakan untuk menyedapkan berbagai masakan. Banyak para ibu, menggunakan jahe sebagai penambah rasa dalam masakannya. Selain itu jahe juga dikenal dapat menjadi minuman yang mampu menghangatkan tubuh.

Jahe sendiri dikenal dengan nama latin Zingiber officinale yang merupakan tanaman yang dikenal sebagai rempah-rempah dan bahan obat tradisional. Yang sejarahnya bahwa jahe ini dipercaya berasal dari negara India. Dari India jahe dibawa sebagai rempah-rempah perdagangan sampai ke Asia Tenggara, Tiongkok, Jepang, hingga Timur Tengah. Yang kemudian jahe tersebut populer sebagai minuman penghangat. Sedangkan ekstrak jahe kering adalah produk hasil pengambilan zat aktif dari tanaman jahe yang dikringkan.

\section{Secang}

Kayu secang merupakan batang dari tanaman dengan buah jenis polong-polongan yang dimanfaatkan untuk dijadikan sebagai rempah-rempah maupun obat herbal. Pohon secang tumbuh subur di India, Asia tenggara dan Pasifik. Pada umumnya bagian kayu atau kulit tanaman inilah yang dimanfaatkan sebagai ramuan atau obat herbal. Ekstrak secang kering adalah membuat kayu secang yang sudah diserut kemudian dikeringkan dibawh sinar matahari alngsug selama duaa hari setelah kering penggunaannya dilaarutkan dalam air panas.

\section{Kapulaga}

Selain sebagai bumbu dapur, rempahrempah Kapulaga juga telah digunakan dalam pengobatan Ayurvedic sebagai pengobatan untuk sariawan, masalah pencernaan, dan bahkan depresi. Beberapa manfaat kesehatan rempah-rempah ini sekarang membuatnya banyak digunakan dalam study modern.
Selayaknya jika kita juga menambahkan kapulaga sebagai salah satu sumber makanan, bukan hanya sebagai penambah rasa saja, tetapi manfaat kesehatan merupakan salah satu yang perlu dipertimbangkan dari kapulaga.Ekstrak kapulaga kering dilakukan dengan cara dipanaskan di sinar matahari selama dua hari.

\section{Daun sereh}

Sereh diaambil batangnya kemudian dipotong kemudian dikerigkan di sinar matahari yang dilakukan selama dua hari.

\section{Daun mint}

Daun mint sebagai pemberi rasa manis serta sensasi dingin dan jadikan juga sebagai bahan pelengkap rasa, daun mint juga mempunyai beberapa faedah besar untuk kesehatan. Ekstrak daun mint adalah dengan membuat kering daun mint yang dilakukan dibawah sinar matahari.

\section{Kandungannya \\ Jahe}

Jahe memiliki beberapa kandungan kimia yang berbeda. Beberapa kandungan kimia pada tiga jenis jahe adalah minyak atsiri, pati dan serat. Selain kandungan-kandungan tersebut, rimpang jahe juga mengandung senyawa fenolik. Beberapa komponen bioaktif dalam ekstrak jahe antara lain (6)-gingerol, (6)shogaol, diarilheptanoid dan curcumin.

Rimpang jahe juga mempunyai aktivitas antioksidan yang melebihi tokoferol.

Kandungan lain yang terdapat pada jahe antara lain minyak atsiri yang terdiri dari senyawa-senyawa seskuiterpen, zingiberen, zingeron, oleoresin, kamfena, limonen, borneol, sineol, sitral, zingiberal, dan felandren. Minyak atsiri umumnya berwarna kuning, sedikit kental, dan merupakan senyawa yang memberikan aroma yang khas pada jahe (Soepardie, 2001)

\section{Kayu secang}

Kandungan yang terdapat pada kayu secang antara lain adalah: Brazilin Polifenol, Flavonoid, Saponin, Tannin, Minyak esensial atsiri. 


\section{Kapulaga}

Tanaman rempah-rempah ini banyak mengandung senyawa kimia yang berfungsi sebagai anti-oksidan yang dapat membantu mencegah penyakit dan menjaga kesehatan. Mengandung banyak minyak atsiri yang penting bagi tubuh, seperti pinene, sabinene, myrcene, phellandrene, limonene, 1, 8-cineole, terpinene, p-cymene, terpinolene, linalool, linalyl asetat, terpinen, a-terpineol, asetat terpineol, sitronelol, nerol, geraniol, metil eugenol, dan trans-nerolidol.

Kapulaga merupakan sumber mineral seperti kalium, kalsium, dan magnesium. dimana kalium merupakan komponen penting dari sel dan cairan tubuh yang membantu mengontrol detak jantung dan tekanan darah. Tembaga dibutuhkan dalam produksi sel darah merah.

\section{Daun sereh}

Daun sereh mengandung $0,4 \%$ minyak atsiri dengan komponen yang terdiri dari sitral, sitronelol (66-85\%), $\alpha$-pinen, kamfen, sabinen, mirsen, $\beta$-felandren, $\mathrm{p}$-simen, limonen, cisosimen, terpinol, sitronelal, borneol, terpinen4-ol, $\alpha$-terpineol, geraniol, farnesol, metil heptenon, n-desialdehida, dipenten, metil heptenon, bornilasetat, geranilformat, terpinil asetat, sitronelil asetat, geranil asetat, $\beta$-elemen, $\beta$-kariofilen, $\quad \beta$-bergamoten, $\quad$ transmetilisoeugenol, $\beta$-kadinen, elemol, kariofilen oksida.1,2,15)

Pada penelitian lain pada daun ditemukan minyak atsiri $1 \%$ dengan komponen utama $(+)$ sitronelol, geranial (lebih kurang 35\% dan $20 \%$ ), disamping itu terdapat pula geranil butirat, sitral, limonen, eugenol, dan metileugenol

\section{Daun mint}

Daun mint (Mentha piperita) merupakan salah satu tanaman herbal aromatik penghasil minyak atsiri yang disebut minyak permen (Ardisela, 2012). Menurut Sastrohamidjojo (2004), bila minyak permen (peppermint oil) diproses lebih lanjut akan diperoleh kandungan menthol. Penyulingan dilakukan pada 70-80\% kandungan menthol pada minyak permen (peppermint oil) dengan cara pengurangan tekanan, sehingga didapatkan bentuk kristal yang berwarna putih dan memiliki bau khas. Oleh karena itu, menthol digunakan secara luas baik dalam bidang obat-obatan, maupun sebagai bahan yang dicampurkan dalam makanan, minuman, pasta gigi (Sastrohamidjojo, 2004).

Menurut Alfath Lafirlaz (2014) minuman jahecang yang ditambah dengan gula batu merupakan minuman tradisional yang berasal dari kata wedang. Wedang atau minuman jahecang adalah minuman dari bahan jahe, secang, kapulaga, cengkeh, daun sereh, ditambah daun mint sebagai perasa segar dan dingin ditambah dengan gula batu dan untuk menghidankan selagi hangat. Menurut Alfat lafirlaz Minuman herbal berbahan rempah ini berkhasiat menghangatkan badan, menghilangkan masuk angin, batuk ringan, melancarkan peredaran darah dan melegakan tenggorokan. Bagi pecandu rokok kretek yang pengin berhenti merokok, minuman ini bisa membantu menghentikan rokok kretek.

\section{Ekstrak jahecang menigkatkan kesehatan}

Masyarakat sekarang banyak yang sudah menggunakan jahecang untuk meningkatkan kesehatan dibuktikan di Desa Japan Kecamatan Sooko yang dahulunyabelum mengenal yang namanya minuman jahecang sekaramg sudah mengenalnya dan banayak yang mencarinya utuk dijadikan minuman untuk capek-capek masuk angin. Menurut penelitian Fitri Rahmawati minuman jahecang merupakan minuman penghangat khas Imogiri, Bantul. Terdapatnya bahan-bahan berkhasiat tersebut dalam jahecang telah terbukti bermanfaat bagi kesehatan, saat ini mulai banyak dicari orang untuk menyelesaikan permasalahan kesehatan terutama dalam pencegahan penyakit degenaratif yang makin banyak ditemui di masyarakat (Masyarakat Perumahan Japan Asri,2017). 


\section{Cara ekstrak jahecang meningkatkan kesehatan}

Bahan jahe, secang, kapulaga, daun sereh, dan daun mint dicuci bersih ,Kemudian dikeringkan di bawah sinar matahari selama dua hari atau lebih, setelah kering diambil satu tiap bahan. Cara minumnya dilakukan dengan cara: Rebus semua dengan api kecil agar zat yang terkandung di dalam semua bahan-bahan dapat keluar dengan sempurna. Kemudain panci ditutup hingga air mendidih dan berwarna kemerahan. Bila tidak direbus diseduh dengan menggunakan air mendidih Tambahkan gula batu atau madu sesuai selera. Sebaiknya gunakan alat perebus yang terbuat dari gerabah atau dari tanah liat karena gerabah bisa mempertahankan aroma dari minuman jahecang. Minum selagi hangat (Edo, Agung, 2013).

Secara alami rempah-rempah mengandung berbagai macam komponen aktif yang sangat besar perannya dalam penciptaan cita rasa suatu produk. Rempah mengandung zat antioksidan, antibakteri, antikapang, antikhamir, antiseptik, antikanker, dan antibiotik, yang kesemuanya itu sangat besar perannya dalam meningkatkan derajat kesehatan masyarakat. Antioksidan tanaman pada umumnya berupa senyawa fenol. Senyawa fenol adalah jenis antioksidan yang paling efektif. Senyawa fenol merupakan jenis antioksidan yang sering digunakan dalam bahan pangan. Di samping senyawa fenol, bahan-bahan alami termasuk rempah-rempah juga mengandung senyawa-senyawa antioksidan lain berupa protein, amin, dan asam-asam organik. Rempah-rempah telah terbukti memiliki senyawa antioksidan yang diperlukan untuk mengatasi serangan radikal bebas. Komponen bioaktif yang berbentuk fenol pada sereh atau serai adalah: sitral dan geraniol; pada jahe, yakni zingiberen, curcumin, filandren, gingerol, dan shogaol; pada cengkih adalah: eugenol, tanin, dan vanilin. Kandungan senyawa aktif yang terdapat di dalam jahe sebagian besar adalah gingerol. Selama proses penyimpanan, gingerol dapat terdehidrasi menjadi shogaol, yang memiliki rasa lebih pedas daripada gingerol. Antioksidan dibedakan atas dua kelompok berdasarkan mekanismenya, yaitu antioksidan primer dan sekunder. Antioksidan primer merupakan antioksidan yang bereaksi dengan radikal lipida yang kemudian mengubahnya menjadi produk yang lebih stabil. Antioksidan primer dapat berupa komponen fenolik, tokoferol alami dan sintetis, alkil galat, butylated hidroksianisol (BHA), butylated hidroksitoluen (BHT) atau tertiary butyl hidroquinon (TBHQ). Antioksidan sekunder bekerja dengan cara mengelat (mengikat) ion logam, menangkap oksigen, mendekomposisi hidroperoksida menjadi spesies nonradikal, menyerap radiasi timbul karena ultraviolet (UV), atau dengan mendeaktivasi singlet oksigen. Radikal bebas secara alami dapat terbentuk di dalam tubuh, sehingga menyebabkan kerusakan sel dan berbagai penyakit. Radikal bebas dan komponen reactive oxygen spesies (ROS) dipercaya berkontribusi banyak pada penyakit manusia, terutama penyakit kronis yang berhubungan dengan penuaan. Konsumsi bahan pangan yang mengandung antioksidan akan membantu tubuh dalam menghambat perkembangan radikal bebas. Rempah-rempah umumnya mengandung komponen bioaktif yang bersifat antioksidan dan dapat berinteraksi dengan reaksi-reaksi fisiologis, sehingga mempunyai kapasitas antimikroba, antipertumbuhan sel kanker, dan sebagainya sehingga dapat menigkatkan kesehatan (Muhammad Yusuf, 2012).

\begin{tabular}{cccc}
\multicolumn{4}{c}{ Tabel 1 Tingkat penggunaan jahecang } \\
\hline No & $\begin{array}{c}\text { Jumlah } \\
\text { masyarakat }\end{array}$ & $\begin{array}{c}\text { Penggunaan } \\
\text { jahecang }\end{array}$ & Prosen \\
1 & & 20 & $50 \%$ \\
2 & Total & 20 & $50 \%$ \\
\hline
\end{tabular}

Dari Tabel 1. Masyarakat yang minum ekstrak jahecang sudah separoh (50\%). Masyarakat sudah menyadari pentingnya 
kesehatan bagi dirinya dan pemanfaatan tanaman obat tradisional sebagai obat non farmakologis dalam meningkatkan kesehatan selain obat farmakologis, Yang selain bahannya murah sedikit efek samping bahkan hampir tidak ada efek samping. Masyarakat juga mulai memahami melestarikan budaya bangsa jamu atau ramua tradisional yaitu minuman jahecang. Dan hasil survey kepada masyarakat setelah minum jahecang yang badannya merasa pegalpegal setalah minum menjadi enak dan bersemangat lagi. Masyarakat yang minum karena masuk angin minum dua kali masuk angina hilang, untuk yang merasa pusing dan tekanan darah tinggi, pengakuan masyarakat pusingnya hilang dan tekanan darah menurun.Selain itu masyarakat mengatakan kalau habis minum jahecang buang air kecil jadi lancer.

\section{Kendala ekstrak jahecang dalam meningkatkan kesehatan masyarakat Masyarakat belum mengerti dosis yang diminum.}

Potensi minuman Indonesia sebagai minuman fungsional masih sangat besar baik sebagai sumber senyawa bioaktif yang memiliki fungsi sebagai antioksidan, anti kanker, hipokolesetrolemia, osteoporosis, anti diare, antimikrobia. Terdapatnya bahan-bahan berkhasiat dalam minuman jahecang telah terbukti bermanfaat bagi kesehatan, saat ini mulai banyak dicari orang untuk menyelesaikan permasalahan kesehatan. Akan tetapi masyarakat belum mengerti dosis minuman jahecang yang diminum dalam sehari dan dalam berapa miggu digunakan.

\section{Bahan baku yang sulit}

Bahan-bahan yang digunakan untuk minuman jahecang sebenarnya mudah didapatkan oleh masyarakat desa yang mempunyai perkebunan luas dan bisa menanam bahan baku minuman jahecang. Masyarakat di Perum Japan Asri masih sulit untuk mencari bahan baku minuman jahecang karena kalau menanam sendiri itu tidak memungkinkan.
Bahan baku yang masih sulit dicari diantara bahan-bahan itu adalah kapulaga dan daun mint.

\section{Masyarakat belum diberikan penyuluhan secara intensif}

Dalam masyarakat Indonesia, pemanfaatan obat tradisional dalam sistem pengobatan sudah membudaya dan cenderung terus meningkat, dan bahan banyak masysarakat yang mencari obat tradisonal. Selain juga didukung tren yang berkembang mengenai makanan kesehatan sekarang ini mulai mengarah kepada bahanbahan yang berasal dari alam dan murni. Akan tetapi masyarakat selama ini belum diberikan penyuluhan secara intensif tentann pengertian dari minuman jahecang, kandungannya, manfaat minuman jahecang. Sehingga perlu sekali utuk diadakan peyuluhan dan bahkan dapat digunakan sebagai tambahan penghasilan masyarakat kalau sudah mengerti cara, dosis dan penggunaannya.

\section{Belum masuk skala komersil}

Minuman jahecang adalah minuman yang dibuat dari rempah-rempah dan untuk menambah sensasi rasa penulis menambahkan daun mint. Minuman jahecang hamper sama dengan minuman wedan uwuh dari Yogyakarta yang meruapakan minuman yang digemari di daerah Ibukota Yogyakarta dan sudah masuk di pemasaran untuk dijual dalam bentuk beranekaragam. Masyarakat di Desa Japan masih kesulitan mencari atau membeli minuman jahecang karena harus ke Yogyakarta. Penulis mencoba mengolah dan mengikuti perlombaan minuman jahecang berbeda dengan di Yogyakarta dengan menambahkan rasa yaitu dari daun mint. Penulis ingin membuat miuman jahecang dikenal di masyarakat dan sebagai produk yang mudah didapat dan bisa diperjualbelikan di kalangan masyarakat Mojokerto.

\section{Aspek sosial (dukungan masyarakat) sebagai bahan kesehatan}

Minuman ekstrak jahecang sebagai minuman kesehatan belum sepenuhnya mendapat dukunagan penuh dari masyarakat, 
sehingga Bapak Bupati Mojokerto mulai memperkenalkan dengan mengadakan lomba minuman kesehatan berbahan dasar secang, yang bertujuan masyarakat lebih mengenal dan lebih memahami bahan-bahan alami alami alam banyak manfaat utuk kesehatan seperti menurunkan kolesterol, tekanan darah tinggi, Diabetes mellitus dan lain-lain.

\section{KESIMPULAN}

1. Minuman ekstrak jahecang dapat meningkatkan kesehatan masyarakat karena bahan-bahan yang digunakan dari bahan dasar alami atau rempah-rempah yaitu jahe, secang kapulaga, sereh, kayu manis, daun mint yang di ekstrak menjadi bahan kering yang pengolahannya dengan cara diseduh dengan air mendidih.

2. Cara atau proses ekstrak jahecang dapat meningkatkan kesehatan masyarakat. Minuman ekstrak jahecang dapat meningkatkan kesehatan masyarakat karena bahan-bahan yang digunakan dari bahan dasar alami atau rempah-rempah yaitu jahe, seang kapulaga, sereh, kayu manis, daun mint. Rempah mengandung zat antioksidan, antibakteri, antikapang, antikhamir, antiseptik, antikanker, dan antibiotik, yang kesemuanya itu sangat besar perannya dalam meningkatkan derajat kesehatan masyarakat

3. Faktor-faktor yang menjadi kendala ekstrak jahecang dalam meningkatkan meningkatkan kesehatan masyarakat adalah belum mengetahui dosis dengan benar, bahan baku yang sulit, masyarakat belum mendapat penyuluhan tetang minuman ekstrak jahecang, belum masuk skala komersil dan dukungan masyarakat sebagai bahan pengobatan untuk meningkatkan kesehaatan.

\section{DAFTAR PUSTAKA}

Anonim, 2011 Kapulaga : Ciri Khas Dan Manfaatnya. http://www.bioactiva.co.id; (10 Agustus 2018)
Alfath Lafirlaz, 2014, Konsumsi Wedang Secang, Laporan Dinas Kesehatan Kulon Progo.http://dinkes.kulonprogokab.go.id/ index.php, Dia akses 10 Agutus 2018

Edo, Agung, 2013, Cara murah menurunkan cholesterol.http://forumkesehatananda.bl ogspot.com/2013/02/cara-murah menurunkan-kolesterol-dan.html. Diakses 10 Agsutus 2018.

Hariana, A, 2007 Tumbuhan Obat dan Khasiatnya, Penebar Swadaya;Jakarta,

https://www.facebook.com/343837535649519/ posts/khasiat-kayu-secang-pada-jahemerah-karomahmay-30-2012bymuhammad-yusuf-pemilik. DiAkses 12 Agustus 2018.

Rahmawati, Fitri, 2011, Kajian Potensi Wedan Uwuh, artikel (http://staffnew.uny.ac.id, di akses 09 Agustus 2018)

Rukmana R, 2000. Usaha Tani Jahe Dilengkapi dengan pengolahan jahe segar, Seri Budi Daya. Penerbit Kanisius, Yogyakarta

Shahidi, F. 1996. Natural Antioxidants. Chemistry, Health Effects, and Applicatins. AOCS Press. Champaign. Illionis.

Skripsi Pengaruh Ekstrak Jahe (Zingiber officinale Rosc.) Erinda Trias Wardani var. 2012. Gajah Terhadap Kualitas Spermatozoa Mencit (Mus musculus) yang Terpapar 2- Methoxyethanol.

Sastrohamidjojo, H. 2004. Kimia Minyak Atsiri. UGM Press. Yogyakarta.

Triyono Agus, 2011 Awal Prihartini, Rohmat Mujahid. Uji Aktivitas Penurun Asam Urat Darah Ekstrak Etanol 70 \% Kayu Secang (Caeselpinia sappan, L) pada Tikus. Balai Besar Litbang Tanaman Obat dan Obat 
Jurnal SainHealth Vol. 3 No. 1 Edisi Maret 2019

(C) Fakultas Ilmu Kesehatan Universitas Maarif Hasyim Latif Sidoarjo

p-ISSN : 2548-8333

e-ISSN : 2549-2586

Tradisional, Tawangmangu, Badan Litbang

Kesehatan.
Yusuf, Muhammad, 2012, khasiat kayu secang pada jahe merah, Dalam Muhammad Yusuf, 2012. https://www.facebook.com, Di akses 12 Agustus 2018. 